\title{
Framework for Analyzing Effects of Spring Load Restrictions
}

\author{
David Levinson, Ning Li, Xi Zou, Brian Smalkoski, and Maryam Hashami
}

Spring load restrictions (SLR) impose restrictions on heavy trucks during the spring thaw period. Although the policies have been implemented for many years, their economic effects on truckers remain uncertain. This study provides an overview of practices around the world and sets up a framework to estimate the benefit-cost of the SLR policy. A freight demand model in Minnesota was built to estimate the impacts of SLR on the freight transportation pattern. The model allows various policy scenarios to be tested before being put into practice. A preliminary result of the freight demand model indicates the SLR policy increased truck vehicle kilometers of travel in Lyon County, Minnesota, by about $13 \%$.

Spring load restrictions (SLR) restrict the axle loading of heavy trucks during the spring thaw. SLR [under various names, including spring (seasonal) weight restrictions, spring bands, or spring thaw load restrictions] are implemented in many countries with cold climates, including the United States, Canada, France, Norway, Finland, and Sweden. The policy aims to minimize pavement damage and extend the useful life of roads, which enables road authorities to save on infrastructure investment and maintenance of roads.

In cold regions, the strength of pavement varies seasonally. During winter, the soil under the pavement surface hardens when temperature drops below the freezing point. When spring arrives, the frozen soil thaws and is in a saturated condition. Under this condition, the soil under the pavement becomes weak and greatly reduces the bearing capacity of the pavement (1). At this time, heavy loads beyond the bearing capacity will cause excessive pavement damage and significantly reduce road life. Historically, it has been found that the amount of damage caused by traffic loads follows a fourth power relationship (2).

To solve this problem, perhaps the most obvious technical solution is to improve pavement capacity of all roads so they can bear heavy loads even during the spring thaw period. However, this is expensive for the responsible agency, and therefore SLR policies are implemented to reduce pavement damage caused by heavy trucks during the thawing period. Figure 1 outlines a set of responses to the problem, including building stronger roads, using SLR, and accepting damages. The objective in this paper is to quantitatively evaluate the effects of SLR in Minnesota and thus find the solution with the minimum total social cost to users and the road agency.

Department of Civil Engineering, University of Minnesota, 500 Pillsbury Drive Southeast, Minneapolis, MN 55455.

Transportation Research Record: Journal of the Transportation Research Board, No. 1874, TRB, National Research Council, Washington, D.C., 2004, pp. 181-188.

\section{REVIEW OF SLR PRACTICES AROUND THE WORLD}

SLR are implemented in many cold regions. For example, in the state of Minnesota, there are nearly $62,750 \mathrm{~km}$ of road subject to SLR, among which are about $2,575 \mathrm{~km}$ of state trunk highways, $37,970 \mathrm{~km}$ of county state aid highways, $3,862 \mathrm{~km}$ of municipal state aid city roads, and $17,700 \mathrm{~km}$ of other local roads (3). The duration of SLR is between 7 and 9 weeks (2).

The United States, Canada, France, Finland, Norway, and Sweden are among the countries that have a SLR policy. Isotalo and the Canadian Strategic Highway Research Program Report discussed the practices in these countries $(4,5)$. The basic information about SLR policy in these countries is presented in Table 1. For most states in the United States, the restrictions take effect in early March and extend through April, typically lasting 8 weeks. In Canada, most provincial primary highway networks are not subject to load restrictions. During the spring thaw period, a $90 \%, 75 \%$ (or $70 \%$ ), and $50 \%$ reduction of the basic allowable weights is typically imposed on other roads. In France, the severe winter of 1962-1963 caused at least $\$ 850$ million in road reconstruction costs (5). France now strives to establish simple indicators and cursory monitoring methods to determine the frost sensitivity. The weight thresholds in France are 3.5 to 9 tons $(18,000 \mathrm{lb})$. Comparatively speaking, Finland has a more unified policy and rich experience in SLR. There are more restrictions in central and eastern Finland than in other parts of the country. The annual saving of road repair cost because of SLR was \$25 million in $1998(4,5)$. Norway placed SLR on $50 \%$ of main roads $(26,000 \mathrm{~km})$ and $80 \%$ of secondary roads $(27,000 \mathrm{~km})$ before 1994 . The SLR reduced allowable axle weights from 10 to 8 tons on main roads and from 8 to 6 tons on secondary roads. In 1995, Norway removed all restrictions and allocated an extra budget of \$20 million to maintain a 10- to 15-year service life for roads. After 4 years of experience, the increased budget has covered the increased damage (6). In Sweden, the decision on restrictions is based on long experience of the behavior of different road sections and the result of frost depth measurement. The road authority even closes nearly $150 \mathrm{~km}$ of roads during the spring thaw (5).

\section{CURRENT EFFORTS IN EVALUATING EFFECTS OF SLR}

The SLR policy will certainly benefit road owners. It will significantly reduce damage to roads and thus extend the service life of roads. Conversely, the SLR policy brings additional cost to some road users. Table 2 presents the costs and benefits of restrictions to both road users and owners. A question naturally arises: does the benefit really exceed the cost? Although the SLR policy has been implemented for many years, the economic effects of SLR are still 


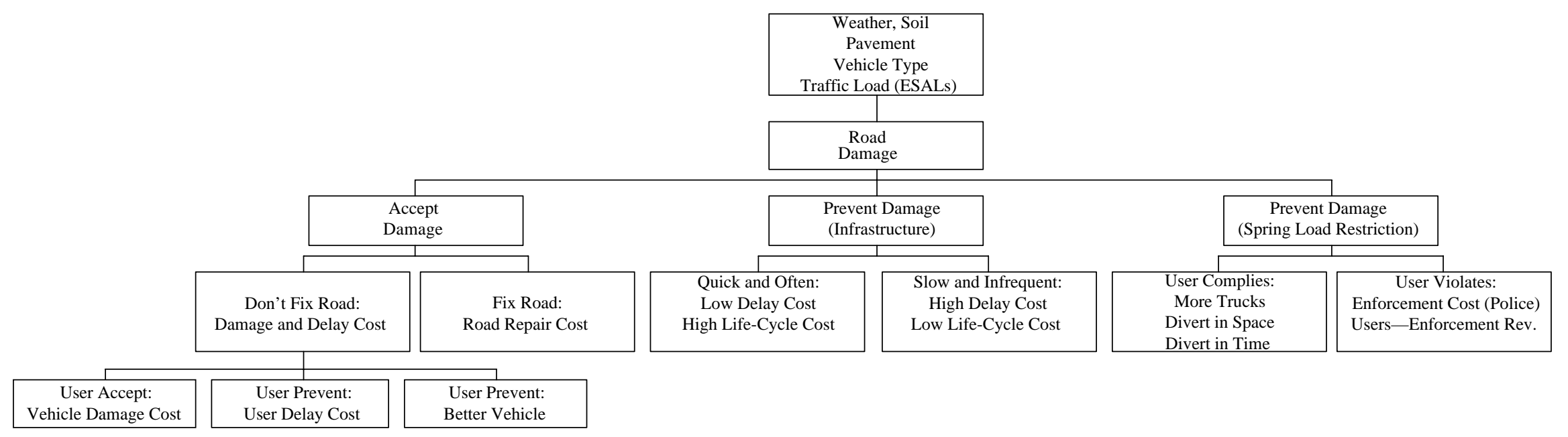

FIGURE 1 Strategies concerning trucks and pavement (ESAL = equivalent single-axle load, Rev. = revenue). 
TABLE 1 Summary of SLR Practices in Various Countries $(4,5)$

\begin{tabular}{|c|c|c|c|c|}
\hline Country & $\begin{array}{l}\text { SLR } \\
\text { Implementation } \\
\end{array}$ & $\begin{array}{l}\text { Measuring } \\
\text { Technique }\end{array}$ & $\begin{array}{l}\text { Weight } \\
\text { Restriction Type }\end{array}$ & Exemptions \\
\hline \multirow[t]{2}{*}{ USA } & \multirow[t]{2}{*}{$\begin{array}{l}\text { More than } 20 \\
\text { states }\end{array}$} & $\begin{array}{l}\text { No uniform } \\
\text { method }\end{array}$ & \multirow[t]{2}{*}{$\begin{array}{l}\text { Axle weight } \\
\text { limit }\end{array}$} & $\begin{array}{l}\text { Vehicle with } \\
\text { permit }\end{array}$ \\
\hline & & $\begin{array}{l}\text { Freezing and } \\
\text { thawing indices } \\
\text { recommended }\end{array}$ & & School bus \\
\hline \multirow[t]{4}{*}{ Canada } & \multirow[t]{4}{*}{ All provinces } & $\begin{array}{l}\text { No uniform } \\
\text { methods }\end{array}$ & \multirow[t]{4}{*}{$\begin{array}{l}\text { Axle weight } \\
\text { limit }\end{array}$} & \\
\hline & & Frost probes & & vehicles \\
\hline & & $\begin{array}{l}\text { Benkelman } \\
\text { beam }\end{array}$ & & $\begin{array}{l}\text { Milk, water, } \\
\text { mail, and buses }\end{array}$ \\
\hline & & $\begin{array}{l}\text { Dynaflect } \\
\text { testing }\end{array}$ & & \\
\hline France & North France & N/A & $\begin{array}{l}\text { Total weight } \\
\text { limit }\end{array}$ & N/A \\
\hline \multirow[t]{4}{*}{ Finland } & \multirow[t]{4}{*}{ Whole country } & \multirow{4}{*}{$\begin{array}{l}\text { Benkelman } \\
\text { beam } \\
\text { measurements } \\
\text { Falling Weight } \\
\text { Deflectometers } \\
\text { (FWDs) }\end{array}$} & \multirow[t]{4}{*}{$\begin{array}{l}\text { Total weight } \\
\text { limit }\end{array}$} & $\begin{array}{l}\text { Emergency } \\
\text { vehicles, buses } \\
\text { Dairy transport }\end{array}$ \\
\hline & & & & $\begin{array}{l}\text { Trucks } \\
\text { supplying retail } \\
\text { shop }\end{array}$ \\
\hline & & & & $\begin{array}{l}\text { Fuel and animal } \\
\text { fodder }\end{array}$ \\
\hline & & & & Permit \\
\hline Norway & $\begin{array}{l}\text { Whole country, } \\
\text { but repealed in } \\
1994\end{array}$ & $\begin{array}{l}\text { Falling Weight } \\
\text { Deflectometer } \\
\text { (FWD), etc. }\end{array}$ & $\begin{array}{l}\text { Axle weight } \\
\text { limit }\end{array}$ & $\begin{array}{l}\text { Dairy and food } \\
\text { delivery }\end{array}$ \\
\hline Sweden & Whole country & FWD & $\begin{array}{l}\text { Axle weight } \\
\text { limit }\end{array}$ & $\begin{array}{l}\text { Dairy and food } \\
\text { delivery }\end{array}$ \\
\hline
\end{tabular}

NotE: N/A = not available

unclear. Quantifying the cost and benefit is difficult because many costs and benefits are intangible and cannot be directly measured. Some efforts have been made to evaluate the effects of SLR, but they still have some limitations.

A World Bank report indicates that the estimated cost savings associated with SLR during an extreme (20-year) winter in Europe are substantial, ranging from $40 \%$ up to $92 \%$, with an average of $79 \%$ for the countries analyzed (4).

FHWA also investigated the benefits of SLR in 1990 (5). The result displays the expected increase in pavement life associated with varying load restrictions. It is clear that seasonal load restrictions can significantly extend useful pavement life (5).

A study in Norway indicated that the cost of SLR exceeded the benefit; therefore, the SLR policy was lifted in 1995 (6). Norwegian authorities set up a model, which assumes that the additional road owner cost without SLR is related to the permitted axle weight, road type (national or regional), traffic load (average daily traffic), pavement type, and so forth. Road user gain was also classified into three categories: direct saving, indirect saving, and time saving.

Contradictions can be seen between the conclusion from the World Bank report and the conclusion from the Norwegian authority. This reflects the complexity of quantifying the actual benefits and costs of SLR.
Because previous methods incompletely evaluated the effects of SLR, this paper strives to build a better model to give a quantitative evaluation of SLR.

\section{FRAMEWORK OF BENEFIT-COST ANALYSIS}

Four counties in Minnesota (Lyon, Clay, St. Louis, and Olmsted) were modeled to estimate the economic effect of SLR policy. Those counties represent typical regions in Minnesota. Lyon County was modeled first to test the methodology.

A flowchart of the framework for analyzing the benefit-cost of SLR is presented in Figure 2. The first step is to obtain the data needed for modeling. A Lyon County geographic information system (GIS) map with traffic volume on most of the roads was obtained from the county traffic engineer together with a detailed load restriction map (7). The GIS map was transformed to EMME/2 format by virtue of Arc/Info and Matlab programming. Freight facilities in Lyon County are located on the map through the Minnesota Department of Transportation freight facilities database.

A two-round SLR survey was conducted in the year 2003 using both mail and on-site interview methods (8). The object of the survey was to provide SLR background information and parameters 
TABLE 2 Costs and Benefits to Road Users and Road Owners

\begin{tabular}{|c|c|c|}
\hline & Costs & Benefits \\
\hline Road user & $\begin{array}{l}\text { Increased Vehicle Kilometers of } \\
\text { Travel (VKT). Because of SLR, } \\
\text { heavy trucks have to detour, which } \\
\text { prolongs travel distances. The cost } \\
\text { equals the increased VKT multiplied } \\
\text { by total truck operation cost per } \\
\text { kilometer. } \\
\text { Inefficient vehicles operation. The } \\
\text { load limitation forces the truck } \\
\text { manager to reduce the load of heavy } \\
\text { trucks and increase the frequency of } \\
\text { trucks, which reduces the efficiency } \\
\text { of trucks. } \\
\text { Indirect effects. SLR affects } \\
\text { industries that rely heavily on heavy } \\
\text { trucks during springtime. For } \\
\text { example, Finland depends heavily on } \\
\text { truck transport for its paper industries, } \\
\text { which requires timing the delivery of } \\
\text { timber. So the paper industry is } \\
\text { greatly affected. Also, SLR restricts } \\
\text { the carrying of some heavy machines. }\end{array}$ & $\begin{array}{l}\text { Reduced road user } \\
\text { construction delay. } \\
\text { Rehabilitation of } \\
\text { pavement can cause } \\
\text { bottleneck of traffic and } \\
\text { increase the accident } \\
\text { rate. SLR can reduce the } \\
\text { frequent maintenance of } \\
\text { the road during spring } \\
\text { thaw. This cost savings } \\
\text { should not be neglected. }\end{array}$ \\
\hline Road owner & $\begin{array}{l}\text { - Enforcement. To ensure the } \\
\text { effectiveness of SLR, enforcement is } \\
\text { needed to guarantee that truck drivers } \\
\text { obey this policy. }\end{array}$ & $\begin{array}{l}\text { Pavement life } \\
\text { extension. Implementing } \\
\text { SLR can extend the } \\
\text { pavement life. This } \\
\text { accounts for a great part } \\
\text { of the benefit. } \\
\text { Annual road } \\
\text { maintenance cost } \\
\text { savings. SLR can protect } \\
\text { pavement from excessive } \\
\text { damage, thus reducing } \\
\text { the annual road } \\
\text { maintenance cost. } \\
\text { Benefits to other light } \\
\text { cars. Speed increase, } \\
\text { reduction of accidents. }\end{array}$ \\
\hline
\end{tabular}

such as truck operating cost, value of time, and trips generated for each freight facility type, which could be used in the benefit-cost analysis.

A four-step freight demand model was implemented to emulate the truck freight pattern in Lyon County. The model calculates the truck trip demand generated in each freight facility within the county, determines their destinations and vehicle chosen based on summary data derived from the survey, and assigns them on each link. The truck volume on each link can then be obtained under two scenarios: no SLR and with SLR.

The total truck vehicle kilometers of travel (VKT) can be calculated for each scenario, and the increased truck VKT due to SLR implementation can be converted to costs by using the parameter of truck operating cost derived from the survey (9).

A pavement team worked on the pavement performance model simultaneously. The outputs of the freight demand model together with other data like pavement material, moisture, and temperature were used as input for the model. The model estimates the pavement life under the two scenarios and the economic benefits of pavement life extension can be derived.

Knowing these costs and benefits, plus other costs and benefits presented in Table 2, makes it possible to estimate the net economic benefit of SLR policy.
The strategies related to the SLR issue should be identified. They are summarized in Figure 1. Each strategy has different costs and benefits and the goal is to find the optimal one with the least total social costs.

- Strategy 1. Implementing SLR during the spring thaw period to protect the roads, which has several substrategies for users:

1. Violate, with resulting fines, or

2. Comply, with a number of techniques, among them getting more trucks, taking other routes, and rescheduling.

- Strategy 2. Repealing SLR and mitigating damages, which has two substrategies:

1. Do frequent preventative rehabilitation and maintenance (quick and often) or

2. Rebuild road stronger (slow and infrequent).

- Strategy 3. Repealing SLR and accepting damages, which has two agency substrategies:

1. Fix road (reactive repair) or

2. Do not fix road. This then engenders at least three user responses:

-User accepts damage,

-User prevents damage by rerouting, or

-User prevents damage with a better vehicle. 


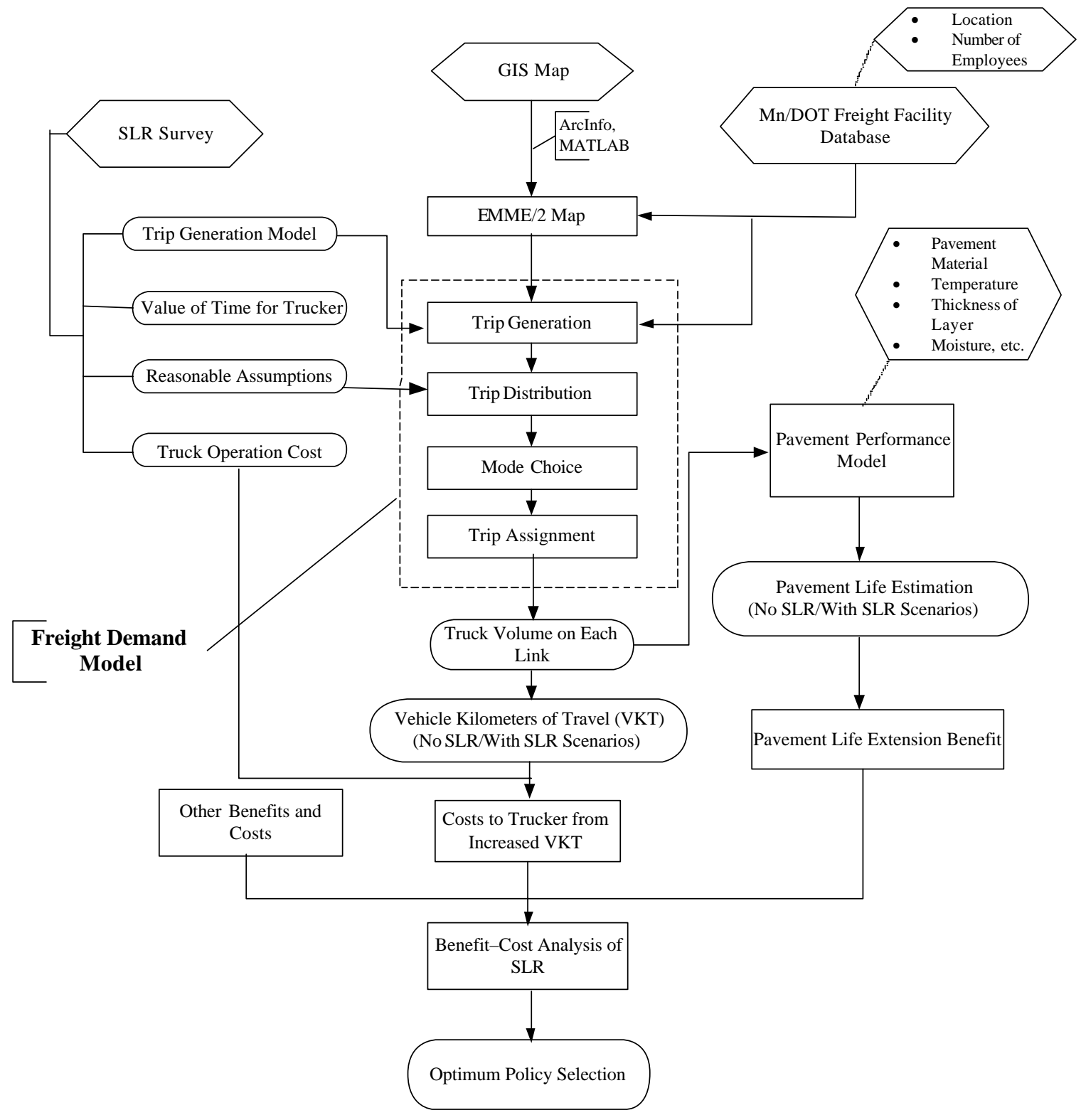

FIGURE 2 Flowchart of SLR benefit-cost analysis (Mn/DOT = Minnesota Department of Transportation).

There are some common benefits and costs between implementing SLR and repealing SLR, but the concern in this paper is with the difference.

The analysis period for SLR is important in the benefit-cost analysis. One possibility is to use the pavement life cycle. Road surfaces deteriorate with age and usage. The quality of riding comfort typically is measured by the present serviceability index (PSI), which was developed in 1957 by AASHO. When the PSI reduces to some level, an overlay is implemented. Implementation of SLR will change the pavement lifetime (Figure 3).

Because the freight demand model is the core element of the framework, it is the focus of the following sections.

\section{FREIGHT DEMAND MODEL}

The objective of the freight demand model is to simulate the impact of SLR on truck flows during the SLR period.

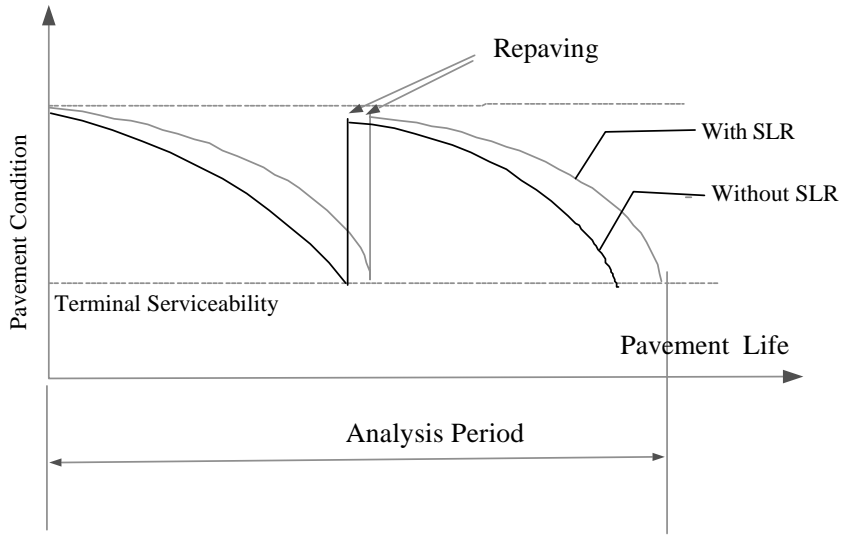

FIGURE 3 Analysis period for pavement life cycle. 


\section{Freight Demand Model Structure}

EMME/2, a transportation-planning program, was chosen to run the four-step freight demand model. Lyon County, Minnesota, was chosen as an example. Roads in Lyon County, including trunk highway, county, city, and township roads, are classified into four types-5-, 7-, 9-, and 10-ton roads-which are consistent with the SLR map obtained from the Lyon County traffic engineer. This number represents the axle weight limit. There are four corresponding modes in the freight demand model $-\mathrm{c}, 1, \mathrm{~m}$, and $\mathrm{h}-$ which are explained in Table 3.

Major freight facilities were located with the Minnesota Freight Facility Database. The following eight land use categories were assumed to be associated with freight transportation: farm, agriculture chemical center, grain elevator, manufacturing plant, retail outlet, trucking facility, wholesale distribution center, and other freight facilities. For farms, the trip generation rate was calculated according to the total weight of grain produced in Lyon County in the year 2001. Total crop weight was 706,484 tons, which was assumed to be carried by a truck fleet with $38.4 \%$ two-axle trucks, $22.3 \%$ three-axle trucks, and $39.3 \%$ five-axle trucks. If the payload of each kind of truck were known (10), the total number of truck trips to carry grain from farm to elevator could be calculated. The total number was 44,681 truck trips. If 225 farms were assumed to be evenly located across Lyon County, each farm would have a daily truck trip rate of 0.60 . For the remaining freight facilities, the trip generation rates were calculated by adopting the model of Mirjam et al. (11), which had a detailed study on freight trip generation by various types of freight facilities. This is a linear regression model:

$$
Y=c+b x
$$

where

$$
\begin{aligned}
Y & =\text { daily freight trip, } \\
b, c & =\text { model coefficients, and } \\
x & =\text { number of employees. }
\end{aligned}
$$

The values of parameters $b$ and $c$ were obtained from Mirjam et al. (11). Table 4 presents the calculated trips.

Trip distribution was based on the origin-destination sketch map in Figure 4. Many assumptions based on the survey results were used to determine the trip distribution pattern. For example, the grain produced in each farm was assumed to go to the nearest grain elevator and the trucks were assumed to return to the farm empty. Each farm was assumed to require the nearest agriculture chemical center to deliver the cargo and the trucks were assumed to return to the agri-

\section{TABLE 3 Four Modes in Freight Demand Model}

\begin{tabular}{lll}
\hline Mode & Representation & Allowed Road Types to Run On \\
\hline $\mathrm{c}$ & Truck with small loads & 5-, 7-, 9-, 10-ton roads \\
1 & Truck with light loads & 7-, 9-, 10-ton roads \\
m & Truck with moderate loads & 9-, 10-ton roads \\
h & Heavy truck & 10-ton roads only
\end{tabular}

TABLE 4 Truck Daily Trip Rate of Other Freight Facilities

\begin{tabular}{lc}
\hline Freight Catalog & $\begin{array}{l}\text { Total Daily } \\
\text { Trip Rate }\end{array}$ \\
\hline Agriculture chemical distribution center & 101.44 \\
Grain elevators & 126.12 \\
Manufacture plant & 67.62 \\
Retail outlet & 128.7 \\
Trucking facility & 159.2 \\
Wholesale outlet & 61.12 \\
\hline
\end{tabular}

culture chemical center empty. For manufacturing, wholesale, retail, trucking facilities, and other facilities, the generated trips of each facility go to the external points outside the county in proportion to the real traffic counts to those external points.

For truck choice, the trips between each origin and destination were assumed to use the heaviest truck allowed. For instance, if the origin is located in a zone that has the highest road type of 7 tons, and the destination is located in a zone that has the highest road type of 9 tons, the trip between the origin and destination can use only up to a minimum of 7 and 9 tons, so the mode would be Mode 1, which has an axle weight limit of 7 tons. If no route that can accommodate Mode 1 can be found linking the origin and destination, the lower level Mode c must be chosen.

In the traffic assignment procedure, truckers were assumed to choose the shortest path assignment. Because rural areas were being modeled, congestion effects were ignored. The volume-delay function was designed to exclude congestion effects. Several EMME/2 macros were written to implement the model.

\section{Calibration and Results}

The model is validated by checking to determine whether predicted counts match the real truck traffic pattern in Lyon County. The only available information is the observed total traffic count map on major roads of Lyon County, which is measured in the year 2000 (Figure 5). If the trucks are assumed to be a certain proportion of the total traffic spread evenly on the roads, the truck pattern should be similar to the real total traffic pattern and the total VKT of trucks should be proportional to the real VKT of the total traffic.

Fortunately, the result of the freight demand model (Figure 6) has a pattern very similar to the observed traffic count in Lyon County. If the truck proportion is assumed to be $12 \%$ of the total traffic volume, the truck VKT of this model then matches $12 \%$ of the observed traffic count VKT. Thus, the model is assumed to be reasonably close to reality, within the bounds of the accuracy of the data.

With this model, two scenarios have been proposed to compare and evaluate the effects of SLR.

- Scenario 1. Truck demand pattern without SLR. In this scenario, all the vehicles can run on any road without load restriction. 


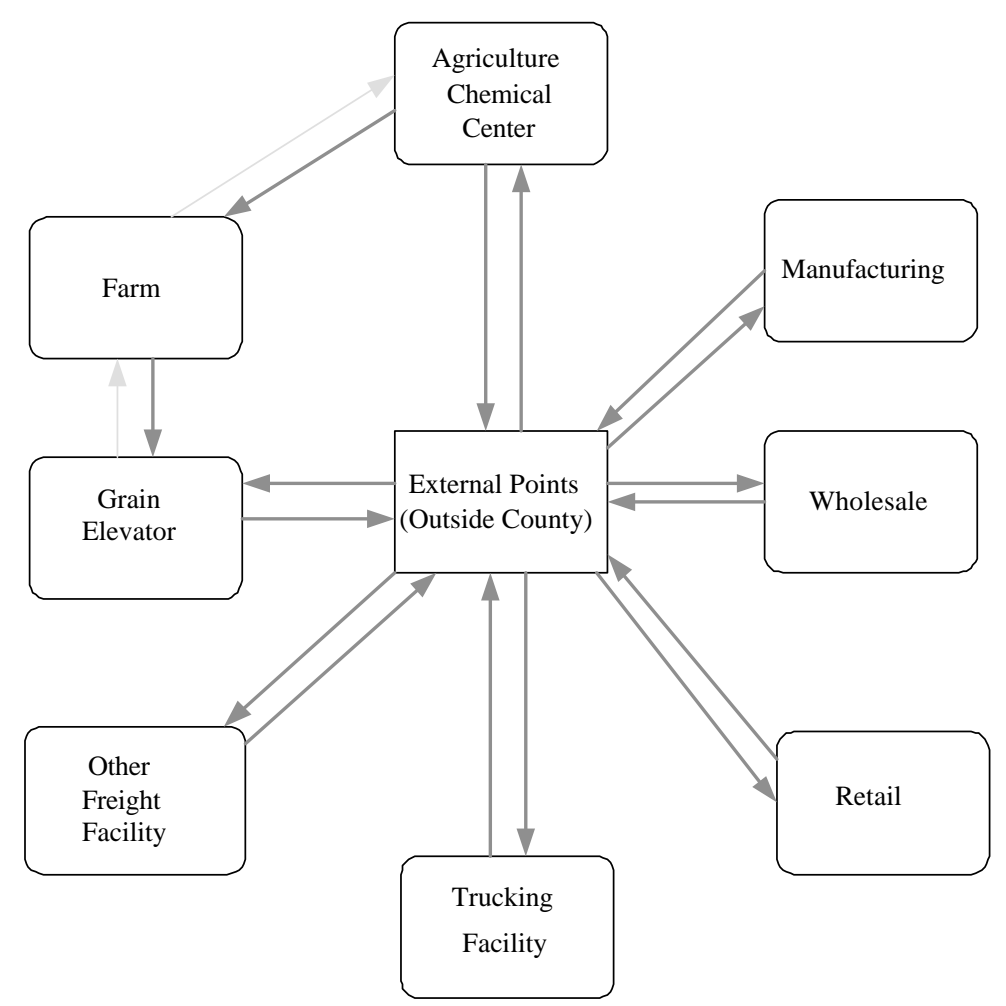

FIGURE 4 Sketch map of origin-destination in Lyon County.

They simply choose the shortest roads. Figure 6 presents the results of this scenario.

- Scenario 2. Truck demand pattern with SLR (full compliance). In this scenario, all the vehicles are assumed to abide by the SLR policy. The truckers do not overload and they have to detour. For the same traffic demand, truckers have to increase the number

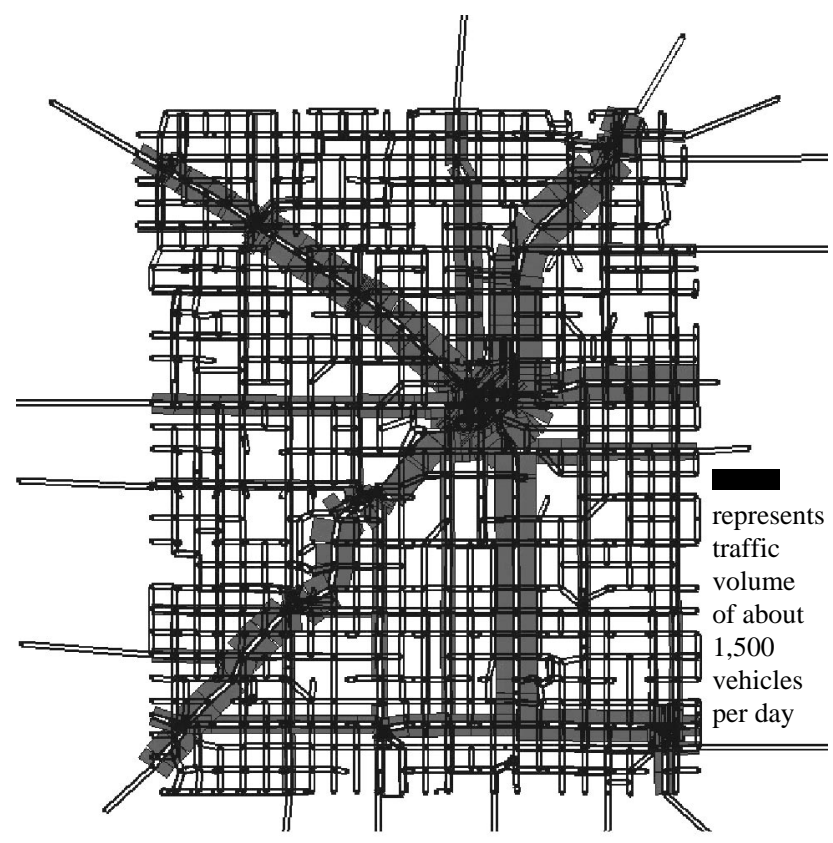

FIGURE 5 Observed total traffic counts map in 2000 (link widths represent magnitude of total traffic volume on each link]. of truckload trips. The results of this scenario are presented in Figure 7.

The VKT of Scenario 1 is $46,720 \mathrm{~km}$, while the VKT of Scenario 2 is $52,800 \mathrm{~km}$. Thus, it can be concluded from the preceding results that implementation of SLR increased truck VKT in Lyon County by $13 \%$.

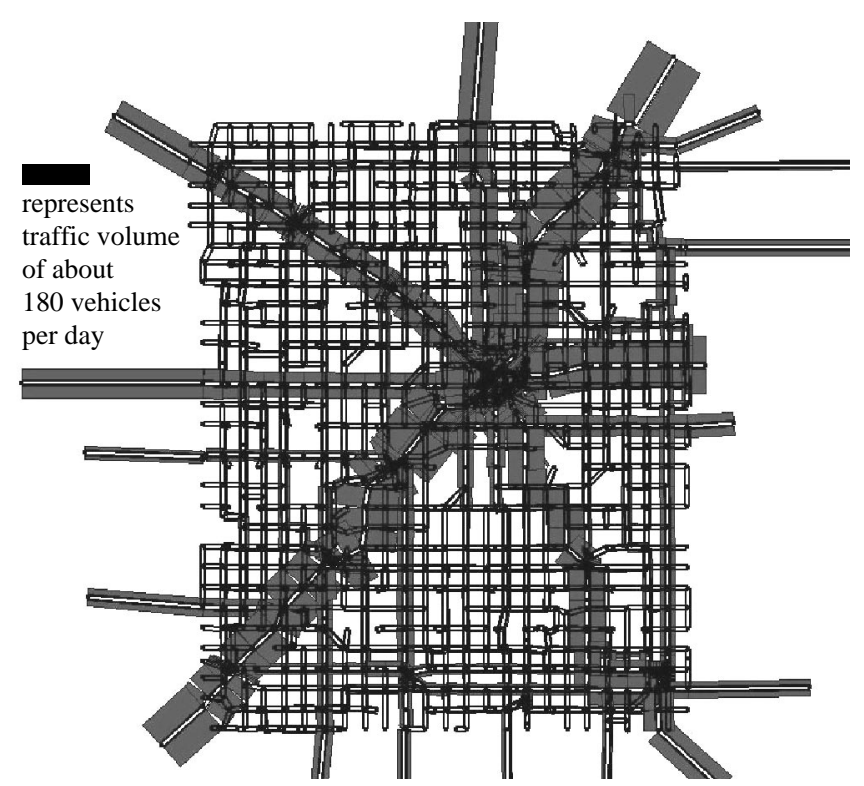

FIGURE 6 Truck volume map from model (Scenario 1, without SLR; link widths represent magnitude of truck traffic volume on each link). 


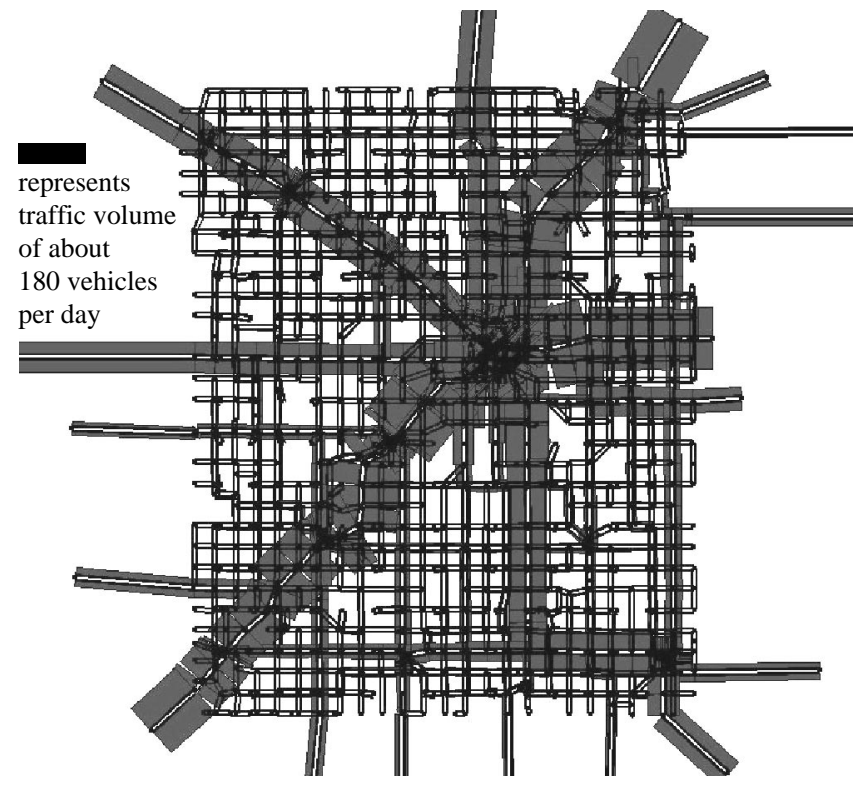

FIGURE 7 Truck volume map from model (Scenario 2, with SLR; link widths represent magnitude of truck traffic volume on each link].

\section{CONCLUSIONS AND FUTURE WORK}

Although SLR has been widely used in cold regions for many years, it is still unclear whether it is economic from the total social cost perspective. The implementation of SLR reduces road damage and thus saves on repair costs for road agencies. But SLR also imposes costs on road users.

In this paper, a framework for performing a benefit-cost analysis of the SLR policy was outlined, which consisted of a SLR survey, a freight demand model, and a pavement performance model. The framework can lead to an efficient policy solution.

The core issue of the framework is to build a freight demand model for Minnesota, which can simulate the impacts of SLR. This model allows various policy scenarios to be tested on the computer before being tested in practice.

A preliminary result of the freight demand model indicates that the enforcement of SLR in Lyon County changed freight transportation patterns and caused a $13 \%$ increase in VKT. On the basis of truck operating costs, this can be converted into the cost imposed on consignees and shippers due to SLR.

A pavement performance model is being built to convert the extra VKT and axle loadings to the reduction of pavement lifetime. Combining this with the cost of pavement repairs allows one to compute the money saved on pavement life extension because of SLR.

Finally, the ultimate benefit-cost analysis of SLR will lead to an efficient policy solution.

\section{REFERENCES}

1. Yukon Infrastructure, Yukon Spring Load Restrictions Brochure. Feb. 2002. http://www.gov.yk.ca/depts/infrastructure/pdf/SWRBrochureV2002Web.pdf. Accessed Feb. 9, 2004.

2. Spring Load Restrictions Task Force Legislative Report. Minnesota Department of Transportation SLR Task Force, St. Paul, Feb. 6, 2001.

3. Ovik, J. M., J. A. Siekmeier, and D. A. Van Deusen. Improved Spring Load Restriction Guidelines Using Mechanistic Analysis. Final Report. Office of Material and Road Research, Minnesota Department of Transportation, St. Paul, July 2000.

4. Isotalo, J. Seasonal Truck-Load Restrictions and Road Maintenance in Countries with Cold Climate. The World Bank Report. The World Bank, Washington, D.C., March 1993. http://www.worldbank.org/transport/ publicat/td-rd14.htm. Accessed Feb. 9, 2004.

5. Seasonal Load Restriction in Canada and Around the World. Canadian Strategic Highway Research Program, Ottawa, Ontario, Canada, Sept. 2000. http://www.cshrp.org/products/brief-21.pdf. Accessed Feb. 9, 2004.

6. Refsdal, G. The Lifting of Axle Load Restrictions During Spring ThawA Norwegian Experiment. Fifth International Conference on the Bearing Capacity of Roads and Airfields, Trondheim, Norway, July 6-8, 1998.

7. Lyon Load Restriction Map (2003) and Traffic Volume Map (2000). Public Works of Lyon County, Marshall, Minn. http://www.lyonco.org/ ept/pw/compplan.html. Accessed Feb. 15, 2004.

8. Smalkoski, B. R. Value of Time for Commercial Vehicle Operators in Minnesota. Master's thesis. University of Minnesota, Minneapolis, Dec. 2003.

9. Hashami, M. Operating Costs for Commercial Vehicle Operators in Minnesota. Master's thesis. University of Minnesota, Minneapolis, Feb. 2004.

10. Trimac Consulting Services Canada. Evaluation of Truck Traffic Patterns and Impacts. Technical Report for Transport Canada Surface Policy and Program, Sept. 15, 1999. http://www.tc.gc.ca/pol/en/Report/ truckGrain1999/C4.htm. Accessed Feb. 9, 2004.

11. Mirjam, H. E., J. Wilhelm, and A. Lori. Freight Trip Generation by Firms. Presented at 42nd European Congress of Regional Science Association, Dortmund, Germany, 2002.

Publication of this paper sponsored by Frost Action Committee. 